\title{
Attitude towards Engineering Ethical Issues: A Comparative Study between Malaysian and Indonesian Engineering Undergraduates
}

\author{
Balamuralithara Balakrishnan ${ }^{1}$, Mohamed Nor Azhari Azman ${ }^{1} \&$ Setyabudi Indartono ${ }^{2}$ \\ ${ }^{1}$ Sultan Idris Education University, Malaysia \\ ${ }^{2}$ Universitas Negeri Yogyakarta, Indonesia \\ Correspondence: Balamuralithara Balakrishnan, Sultan Idris Education University, Malaysia.
}

Received: December 1, 2019

Accepted: December 26, 2019 Online Published: December 27, 2019

doi:10.5430/ijhe.v9n2p63

URL: https://doi.org/10.5430/ijhe.v9n2p63

\begin{abstract}
This investigation addressed the outcomes of a comparative study on attitude towards engineering ethical issues between engineering undergraduates of Malaysia and Indonesia. The study was conducted involving 83 Malaysian and 135 Indonesian undergraduates who pursuing their study in engineering programmes. A quantitative method was used in which a questionnaire was administrated to elicit relevant data. The outcomes of the data analysis showed that the attitude towards engineering ethical issues among Indonesian engineering students was positive and significantly higher than Malaysian engineering students. These findings revealed that various pedagogical approaches for teaching engineering ethics course will have positive impact on students' attitude towards ethics. Therefore, the study findings opens up a new dimension in ethics education which highlighting the importance of teaching strategies in developing the attitude towards engineering ethical issues. This is vital in facilitating in the development of holistic and ethical engineers.
\end{abstract}

Keywords: engineering ethics education, attitude, engineering undergraduates, pedagogy

\section{Introduction}

In the era of science and technology development the need for concentration on sustainability issues of environment and well being of society. These issues concerning every single member of society, including engineers. Engineers actively involved in activities that concerning on these above mentioned issues whereby it is the responsibility of the engineers to protect the environment and take care the well being of the mankind.

In order to achieve this, it is pivotal for engineers to manage properly their commitments towards their employers and their duties towards society and environment at large. Majority of engineering programmes around the globe have introduced a course on ethics that plays an important role to educate the future engineers with the appropriate knowledge, skills and importantly values that covers multi-dimensions of ethical elements. The dimensions are as followings: (i) engineering profession, (ii) society, (iii) economic and (iv) environment which ultimately instill the spirit of socio-responsibility. Harris et al. (2013) cited that engineering ethics education in engineering programmes is to prepare the engineering undergraduates - future engineers - to carry out their duties professionally with sense of responsibility towards the society and bio-sphere. Thus, engineering ethics education was made a compulsory subject as part for the conditions for accreditation in many countries.

Engineering ethics education is one of the vital component for any engineering programme since ethical responsibility and ethical decision making capability are necessary traits for every professional engineers. Since professional engineers will be dealing with multiple ethical issues, it is essential for the future engineers to be well prepared to face these challenges diligently and it is the role of engineering ethics educators to educate the engineering undergraduates to confront with various dimension of ethical issues that may cause harm to the well being of community and environment (Balakrishnan et al., 2019).

Engineering Accreditation Council of Malaysia (EAC) and Indonesian Accreditation Board for Engineering Education (IABEE) have emphasized that all engineering undergraduates must undergo the ethics course during the study. The ultimate purpose of this course is to build holistic engineers who has strong professional values who is able to act and take decision ethically. Fundamental topics such as professional code of ethics, sustainability issues, ethical decision making, environmental issues and other related subjects are taught in engineering ethics course to engineering undergraduates with the aim to develop socio-responsible engineers in future. 
There are many various methods of teaching adapted by engineering ethics educators to teach engineering ethics education. Bielefeldt et al. (2016) cited that there is yet a single best pedagogical practice has emerged for engineering ethics education. Large group lecture session, guest lectures, blended learning, online learning and other teaching strategies have been utilized by educators to teach engineering ethics education (Balakrishnan et al., 2019). Delany et al. (2016) asserted that different teaching methods brings different advantages for the cognitive and affective development among the undergraduates. At the same time, it is pivotal to scrutinize whether the knowledge and values that gained in the engineering ethics classroom have carved an appropriate attitude towards ethics among the engineering undergraduates. Attitude determines the action and thinking of an individual towards a certain issue (Bauman \& May, 2019) and this is important for future engineers to possess appropriate attitude towards ethical issues since positive attitude will lead for positive action and mindset.

Therefore, in this study, the researchers aimed to gauge and compare the attitude towards engineering ethics issues among Malaysian and Indonesian engineering undergraduates. This investigation is timely and essential since both countries have placed importance on in developing ethical engineers who has high sense of responsibility (Widiasanti \& Tamin, 2015). Moreover, comparison study between two countries - Malaysia and Indonesia - in the context of engineering ethics education is not a well researched area. The outcomes of the study could serve as a cornerstone for engineering ethics educators to re-visit their current pedagogical approaches in molding the attitude of their students towards engineering ethical issues in which it will be leading them to enhance their teaching approaches to achieve the subject outcomes.

\section{Engineering Ethics Education}

Barakat (2011) pointed out that professional ethics of any disciplines not originated from cultural norms but it is a set of rules that originated from the characteristics of the profession's activity. Herket (2005) said that "engineering professional ethics is concentrated on the relationship between the professional engineers, client, colleagues and employers, or on collective responsibility of the profession" (p.374). While Barakat (2011) cited that "engineering ethics is a wide framework that brings most of the non-technical aspects of the professions, including the professional, human and societal ones into engineering practice" (p.160).

In nutshell, engineering ethics consists the combination of three main factors (i) social; (ii) economical and (iii) environment that carve the path for engineers to think and act ethically to protect the public interest regardless of any external pressure from their employers (Cheruvalath, 2019). As such, it will be leading the engineers to be more socially responsible in dealing with ethical dilemmas.

Future engineers - engineering undergraduates- should understand their responsibilities as an engineer to their employers, clients and as well as to the society. At the same time, in this era, the future engineers should also be aware of their actions and the consequences of their actions in engineering practices to mankind and earth. Engineering ethics education must prepare the engineering undergraduates to be competent engineers who are sensitive towards ethical issues. Moreover, they must be able to act and solve those issues appropriately. The challenges in engineering professions come in many dimensions such as in technology, scientific, humanistic and environment. Thus, it is the utmost responsibility of the engineering ethics educators to instill the ethical values that could develop an appropriate attitude towards ethical issues that overarching those dimensions among the undergraduates.

Pedagogical approaches in teaching and learning process in engineering ethics classrooms play a pivotal role in delivering the knowledge, skills and values effectively to the engineering undergraduates. Balakrishnan et al. (2019) found that different /multiple innovative approaches in teaching engineering ethics education could produce engineering undergraduates who possess positive attitude.

Educators have come with many innovations that could improve the instructions of engineering ethics education in many higher education institutions around the globe. Hess and Fore (2018) have summarized the following pedagogical approach that utilized by educators to deliver engineering ethics education course to engineering undergraduates:
a) Lecture
b) Guest Lecture
c) Service Learning
d)Blended Learning
e) Game based Learning and etc. 


\section{Engineering Ethics Education in University A, Malaysia}

In Malaysia, Engineering Accreditation Council of Malaysia (EAC) has imposed a requirement for every engineering program in Malaysia to offer at least one course that educate the undergraduates on engineering ethics education (Balakrishnan et al., 2013). In University A, engineering ethics education taught as stand-alone subject whereby it is known as "Engineers in Society". The subject consists of the following topics:

a) Engineering Ethics and Professional Code of Conduct

b) Sustainability Issues in Engineering Profession

c) Science and Technology Development

d) Globalization in Engineering World

This subject is a THREE credit hour course which divided into two hours of lecture and one hour of tutorial. The pedagogical approach that utilized in both classes - lecture and tutorial- is a traditional method. Besides that, the students need to accomplish an assignment as part of their coursework whereby the assignment consists of several case studies that the students need come with ethical solution for each case.

\section{Engineering Ethics Education in University B, Indonesia}

Indonesian Accreditation Board for Engineering Education (IABEE) has emphasized the importance of ethics education through its criterion for engineering programme accreditation (IABEE, 2019). Ethics education is one of the amjor component for developing ethical undergraduates which is in-line with the aspiration of Long Term Development Mission of Indonesia 2005-2025 (Vazquez, 2019). Ethics have been taught in University B in a subject called Professional Ethics for Engineers. The topics of the subject are as following:

a) Science and Technology Development

b) Ethics Philosophies

c) Professional Engineering Ethics

d) Intellectual Properties

The subject is taught through lecture class and at the same time, professional engineers also invited to give lecture in guest lecture session. This session - guest lecture - focuses on sharing the experiences of professional engineers in dealing with ethical issues at workplace. Moreover, the students need to accomplish a community service project as part of their coursework. This service learning approach concentrate on serving the surrounding community, solving the public problems via engineering knowledge and skills

\section{Methodology}

Lathem et al. (2011) cited that attitude plays an important role in determining the application of knowledge and skills in proper direction. In the context of engineering ethics education, it is vital for engineering undergraduates to develop a positive attitude towards ethical issues in order for them to carry out their duties responsibly and most important ethically. Thus, assessing students' attitude towards ethical issues provides a better insight on the impact of engineering ethics education in educating and preparing future engineers who can deal with ethical issues professionally.

The aims of this investigation are as followings:

Ra: to examine the attitude towards ethical issues among engineering undergraduates of University A, Malaysia and University B, Indonesia

$\mathrm{Rb}$ : to compare the attitude towards ethical issues between engineering undergraduates of University $\mathrm{A}$, Malaysia and University B, Indonesia

In this study, two groups of students comprises 83 engineering undergraduates of University A, Malaysia and 130 engineering undergraduates from University B, Indonesia. They were pursuing their studies in Electrical, Chemical and Mechanical engineering. The respondents were recruited through stratified sampling in which each respondents should be in their final year of study and had successfully pursued engineering ethics course in their respective institutions with a minimum achievement of grade B - achieved minimum marks of $70 \%$. The recruitment process of these respondents was assisted by full cooperation given by the authority of both universities. 
A questionnaire was administrated among the participants of the study that contains several statements associated to ethical issues in engineering profession. Each statement of the questionnaire uses a 5 point Likert-type scale, ranging from point 5 (strongly agree) to point 1 (strongly disagree).

The items for the questionnaire that gauge the attitude towards engineering ethical issues were adapted from the studies that utilized in both studies of Balakrishnan et al. (2013) and Balakrishnan et al. (2019).

\section{Results and Discussion}

The data obtained was evaluated using Statistical Package for Social Science (SPSS). The Cronbach Alpha co-efficient of reliability - value for the questionnaire were 0.847 which deemed to be reliable (Creswell, 2013). At the same time, the data collected were tested to be normally distributed, hence, parametric test can be used to measure the comparison as addressed in second objective of this study. To answer the second objective; paired two-tailed t test were conducted for each statement to analyzed the comparison of the differences in students' attitude towards engineering ethical issue among the respondents of both universities. Table 1 shows the mean score and standard deviations of Malaysian and Indonesian engineering students' responses to each item in the questionnaire. Table 2 illustrates the $\mathrm{t}$-values of paired two-tailed t-test.

Table 1. The mean score and standard deviations of Malaysian and Indonesian engineering undergraduates

\begin{tabular}{|c|c|c|}
\hline Statement & $\begin{array}{l}\text { Mean (M) } \\
\text { (Malaysia/ } \\
\text { Indonesia) }\end{array}$ & $\begin{array}{c}\text { Standard } \\
\text { Deviation(SD) } \\
\text { (Malaysia/ } \\
\text { Indonesia) }\end{array}$ \\
\hline $\begin{array}{l}\text { A1: I am confident to deal with engineering problems } \\
\text { ethically. }\end{array}$ & $2.81 / 4.11$ & $0.40 / 0.31$ \\
\hline $\begin{array}{l}\text { A2: I am aware of the role of engineers in today's } \\
\text { society. }\end{array}$ & $2.72 / 4.23$ & $0.23 / 0.21$ \\
\hline $\begin{array}{l}\text { A3: I am aware of the influence of engineering on } \\
\text { economic issues. }\end{array}$ & $2.95 / 4.03$ & $0.18 / 0.09$ \\
\hline $\begin{array}{l}\text { A4: I am aware of the effect of engineering activities on } \\
\text { the environment. }\end{array}$ & $2.53 / 4.13$ & $0.22 / 0.11$ \\
\hline $\begin{array}{c}\text { A5: I am aware of the influence of engineering on } \\
\text { mankind. }\end{array}$ & $2.63 / 4.22$ & $0.32 / 0.20$ \\
\hline $\begin{array}{l}\text { A6: I believe in the significance of ethics in every } \\
\text { decision-making process. }\end{array}$ & $2.81 / 4.10$ & $0.27 / 0.03$ \\
\hline $\begin{array}{l}\text { A7: I believe in the significance of being sensitive to the } \\
\text { public's views in engineering design /projects. }\end{array}$ & $2.75 / 4.08$ & $0.18 / 0.02$ \\
\hline $\begin{array}{l}\text { A8: I believe in the seriousness of sustainability issues in } \\
\text { engineering design /projects }\end{array}$ & $2.85 / 4.12$ & $0.24 / 0.08$ \\
\hline
\end{tabular}


Table 2. The t-values of paired two-tailed t-test

\begin{tabular}{|c|c|}
\hline Statement & t-value \\
\hline $\begin{array}{l}\text { A1: I am confident to deal engineering problems } \\
\text { ethically }\end{array}$ & $5.01 *$ \\
\hline $\begin{array}{c}\text { A2: I am aware of the role of engineers in today's } \\
\text { society }\end{array}$ & $4.97 * *$ \\
\hline $\begin{array}{l}\text { A3: I am aware of the influence of engineering on } \\
\text { economic issues }\end{array}$ & $4.87 *$ \\
\hline $\begin{array}{l}\text { A4: I am aware of the aware of engineering activities } \\
\text { on the environment }\end{array}$ & $5.12 *$ \\
\hline $\begin{array}{c}\text { A5: I am aware of the impact of engineering on } \\
\text { mankind }\end{array}$ & $4.98 *$ \\
\hline $\begin{array}{l}\text { A6: I believe in the significance of ethics in every } \\
\text { decision-making process }\end{array}$ & $5.02 *$ \\
\hline $\begin{array}{l}\text { A7: I believe in the significance of being sensitive to } \\
\text { the public's views in engineering design /projects }\end{array}$ & $4.23 *$ \\
\hline $\begin{array}{l}\text { A8: I believe in the seriousness of sustainability issues } \\
\text { in engineering design /projects }\end{array}$ & $4.78^{*}$ \\
\hline
\end{tabular}

Referring to Table 1, it shows that the mean scores of Indonesian respondents' attitude towards engineering ethical issues were high, ranging from $4.23(\mathrm{SD}=0.21)$ to $4.03(\mathrm{SD}=0.09)$. On the other hand, the respondents from Malaysia responded the questionnaire with lower mean scores that ranged from $2.63(\mathrm{SD}=0.32)$ to 2.95 ( $\mathrm{SD}=0.17)$. It is clear that the attitude of Indonesian engineering students of this investigation towards engineering ethical issues was better than Malaysian engineering students. Attitude development among the Indonesian engineering undergraduates may contributed by different pedagogical approaches that utilized by engineering ethics educators in University B, Indonesia. Horng et al. (2019) found that various teaching methods for ethics education course could give a better impact on students in acquiring the fundamental values of ethics.

The differences in the attitude towards engineering ethical issues between Malaysian and Indonesian students of both University A, Malaysia and University B, Indonesia were ascertained via the $t$-values of the paired two-tailed t-test (referring to Table 2) that revealed that all the differences in the respondents' item were significant. It is clearly shows that the differences in the attitude towards ethical issues between Indonesian and Malaysian engineering undergraduates were differed significantly. These results - t-test- gave a better view on the impact of developing the attitude among the undergraduates of both universities via engineering ethics course that preached in their respective institutions.

Apparently, engineering ethics education in University B, Indonesia has a positive impact in developing the attitude among the engineering undergraduates in dealing with engineering ethical issues. Bielefeldt et al. (2016) asserted that engineering ethics education should covers two main domains of learning, knowledge and affective which deemed to be pivotal in ethics education outcomes. The engineering ethics education practice in University B, Indonesia that combines traditional lecture classes, guest lecture sessions and service learning through community engagement have facilitated the students to go beyond the knowledge gaining whereby it also helped them to acquire the appropriate ethical values that essential for attitude development .

At the same time, the community service activities in engineering ethics education of University B, Indonesia benefits the students instilling positive attitude. Bielefeldt and Canney (2018) found that community engagement facilitate the engineering ethics educators to develop appropriate attitude especially in the context of social responsibility. Litchfield et al. (2016) mentioned that learning ethics through service learning is a good platform to teach ethical issues pertaining to the society and environment.

Prefier and Billiar (2017) cited that participation from professional engineers in engineering ethics classroom make the learning process more stimulating and realistic. Guest lecture session that practiced in engineering ethics course in University B, Indonesia is one of the effective way to cultivate good attitude towards ethical issues among the students whereby Skirpan et al. (2018) found that guest lecture could excite students to engage actively in the ethics 
course in which it will help them to visualize the importance of ethics in engineering profession in which typical traditional lecture class could not deliver it.

Effective teaching methods for engineering ethics education are important to carve the path for engineering students to build themselves with proper attitude who has sense of responsibility towards mankind and environment. Educators play a vital role to engage the students in learning ethics efficiently through various effective teaching methods that suitable and useful.

In nutshell, engineering ethics educators of University A, Malaysia must relook at the current pedagogical approaches that utilized in engineering ethics classrooms since the attitude of the engineering undergraduates towards ethical issues not promising compared to engineering undergraduates of University B, Indonesia who have positive attitude. This is mainly contributed by the effective teaching strategies that adopted by the educators in University B, Indonesia to teach engineering ethics course.

Thus, educators and other related stakeholders of engineering ethics education should concentrate on the pedagogical aspect since it contributes in the development of appropriate attitude towards ethical issues which is pivotal to produce an holistic engineer in future.

Good attitude towards ethical issues will ensure the future engineers not only have strong technical knowledge and skills but also good mindset and spirit to serve mankind and earth responsibly.

\section{Conclusions}

The study has projected findings with the regard to engineering ethics education in University A, Malaysia and University B, Indonesia. The attitude towards engineering ethical issues among the undergraduates of University B, Indonesia was better and positive in comparison to the respondents of University A, Malaysia. Moreover, there were significant differences in all items that used to gauge the level of attitude among the respondents between University A, Malaysia and University B, Indonesia.

A well structured with multiple approaches of teaching engineering ethics education assist the engineering undergraduates to develop appropriate attitude towards ethical issues. Moreover, service learning via community engagement and inviting professional engineers have proven beneficial to develop positive attitude and push the students to go beyond the cognitive domain of learning, embracing the appropriate values that required for a socio-responsible engineer.

\section{Acknowledgement}

This research has been carried out under Matching Research Grant of Universiti Pendidikan Sultan Idris and Universitas Negeri Yogyakarta (Research Code: 2019-0242-107-01) provided by Sultan Idris Education University, Malaysia.

\section{References}

Balakrishnan, B., Er, P. H., \& Visvanathan, P. (2013). Socio-ethical education in nanotechnology engineering programmes: A case study in Malaysia. Science and engineering ethics, 19(3), 1341-1355. https://doi.org/10.1007/s11948-012-9418-z

Balakrishnan, B., Tochinai, F., \& Kanemitsu, H. (2019). Engineering ethics education: A comparative study of Japan and Malaysia. Science and engineering ethics, 25(4), 1069-1083. https://doi.org/10.1007/s11948-018-0051-3

Barakat, N. (2011, April). Engineering ethics: A critical dimension of the profession. In 2011 IEEE Global Engineering Education Conference (EDUCON) (pp. 159-164). IEEE. https://doi.org/10.1109/EDUCON.2011.5773130

Bauman, Z., \& May, T. (2019). Thinking sociologically. John Wiley \& Sons.

Bielefeldt, A. R., \& Canney, N. E. (2016). Changes in the social responsibility attitudes of engineering students over time. Science and engineering ethics, 22(5), 1535-1551. https://doi.org/10.1007/s11948-015-9706-5

Bielefeldt, A. R., Canney, N., Swan, C., \& Knight, D. W. (2016). Contributions of learning through service to the ethics education of engineering students. International Journal for Service Learning in Engineering, Humanitarian Engineering and Social Entrepreneurship, 11(2), 1-17. https://doi.org/10.24908/ijsle.v11i2.6392

Cheruvalath, R. (2019). Does Studying 'Ethics' Improve Engineering Students' Meta-Moral Cognitive Skills?. Science and engineering ethics, 25(2), 583-596. https://doi.org/10.1007/s11948-017-0009-x 
Delany, C., Kosta, L., Ewen, S., Nicholson, P., Remedios, L., \& Harms, L. (2016). Identifying pedagogy and teaching strategies for achieving nationally prescribed learning outcomes. Higher Education Research \& Development, 35(5), 895-909. https://doi.org/10.1080/07294360.2016.1138450

Harris Jr, C. E., Pritchard, M. S., Rabins, M. J., James, R., \& Englehardt, E. (2013). Engineering ethics: Concepts and cases. Cengage Learning.

Herkert, J. R. (2005). Ways of thinking about and teaching ethical problem solving: Microethics and macroethics in engineering. Science and Engineering Ethics, 11(3), 373-385. https://doi.org/10.1007/s11948-005-0006-3

Hess, J. L., \& Fore, G. (2018). A systematic literature review of US engineering ethics interventions. Science and engineering ethics, 24(2), 551-583. https://doi.org/10.1007/s11948-017-9910-6

Horng, J. S., Hsu, H., \& Tsai, C. Y. (2019). Learning corporate ethics and social responsibility: Developing an influential curriculum for undergraduate tourism and hospitality students. Journal of Hospitality, Leisure, Sport \& Tourism Education, 24, 100-109. https://doi.org/10.1016/j.jhlste.2019.01.003

IABEE(2019). https://iabee.or.id/en/accrediation/accreditation-criteria/criteria-guide/ Accessed on 1 July 2019.

Lathem, S. A., Neumann, M. D., \& Hayden, N. (2011). The socially responsible engineer: Assessing student attitudes of roles and responsibilities. Journal of Engineering Education, 100(3), 444-474. https://doi.org/10.1002/j.2168-9830.2011.tb00022.x

Litchfield, K., Javernick-Will, A., \& Maul, A. (2016). Technical and professional skills of engineers involved and not involved in engineering service. Journal of Engineering Education, 105(1), 70-92. https://doi.org/10.1002/jee.20109

Pfeifer, G., \& Billiar, K. (2017). Teaching Ethics in the Context of Engineering Courses: A Blended Approach of Theory and Practice. In 124th ASEE Annual Conference and Exposition, June. https://doi.org/10.18260/1-2--28916

Skirpan, M., Beard, N., Bhaduri, S., Fiesler, C., \& Yeh, T. (2018, February). Ethics education in context: A case study of novel ethics activities for the CS classroom. In Proceedings of the 49th ACM Technical Symposium on Computer Science Education (pp. 940-945). ACM. https://doi.org/10.1145/3159450.3159573

Vazquez, K. C. (2019). Learning from Peers: How Brazil and Indonesia Are Structuring Institutional and Operational Models for South - South Knowledge Exchange1. Innovating South-South Cooperation: Policies, Challenges and Prospects, 329. https://doi.org/10.2307/j.ctvnp0kv2.18

Widiasanti, I., \& Tamin, R. Z. (2015, February). A Review on Certification Procedure for Professionals Engineer based on Engineering Act in Indonesia. International Conference on Coastal and Delta Areas, 1(1), 254-262. 